\title{
Effects of fire on scuttle flies (Diptera: Phoridae) in a pine forest in Poland
}

\author{
Ewa Durska
}

\begin{abstract}
Durska, E. 2015: Effects of fire on scuttle flies (Diptera: Phoridae) in a pine forest in Poland. - Entomol. Fenica 26: 181-193.

Ecological consequences of fire on the scuttle fly communities were investigated in a pine forest in Poland (Garwolin Forest). Data from 1,243 identifiable individuals, representing 48 species, were used. The scuttle fly communities in fire-affected plots were similar in terms of the number of species but less diverse than those in an undisturbed reference plot. The response of the flies to the fire was species-specific. Four Megaselia species (M. brevicostalis, M. nigriceps, $M$. elongata and $M$. obscuripennis) were most numerous in the plot most affected by fire. Approximately three years after the fire the scuttle fly communities were relatively similar to those found in a clear-cut pine plantation (Białowieża Primeval Forest) as well as to those in post-windthrow habitats (Pisz Forest) in which logs were removed or left. The Megaselia species are the winners in the fire affected habitats and seem to be more stress-tolerant than other genera of the scuttle flies.

E. Durska, Department of Ecology and Biodiversity, Museum and Institute of Zoology, Polish Academy of Sciences, Wilcza 64, 00-679 Warsaw, Poland; E-mail:edurska@miiz.waw.pl
\end{abstract}

Received 8 May 2015, accepted 28 July 2015

\section{Introduction}

In sub-boreal forests, burned wood provides food, shelter or sites of reproduction for a large number of living organisms. The smoke and heat following fire lures pyrophilous insects, and the modified forest habitat attracts saproxylic species (Lyon et al. 1978, Holliday 1984, Holliday 1991, Moretti et al. 2006). These species are crucial to the decomposition of coarse woody debris and to nutrient cycling after disturbances (Speight 1989, Cobb et al. 2011, Keville et al. 2013, Lee et al. 2014). Fires have a major impact on soil, and these changes have implications for litter-dwelling organisms (Vincent et al. 2009 and literature therein). Burnt trees are utilized as breeding material and nutrient sources (fast-growing post-fire fungi) by saproxylic, secondary saproxylic (sensu Speight 1989) and sapro/mycophagous species, which are largely scuttle flies (Disney 1994, Toivanen \& Kotiaho 2007, Disney \& Pagola-Carte 2009, Durska 2013). The larvae of a great number of different Diptera are connected with the humification phase, living in wet decaying wood or in tree holes (Speight 1989).

Natural and anthropogenic disturbances in forest ecosystems, e.g. forest fires, are components of ecosystems worldwide. They provide open areas required by many species and may have both advantageous and negative impacts on habitats (Sousa 1984, Platt \& Connell 2003). Disturbances contribute to biodiversity by increasing spatial heterogeneity (Fox 1979, Knisley 2011 and literature therein). 


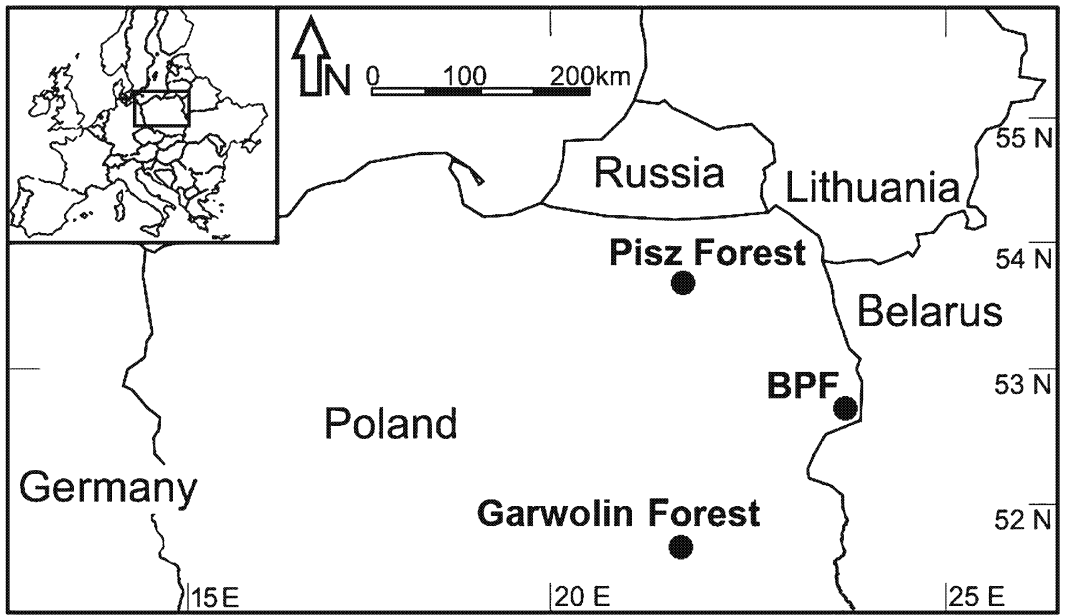

Fig. 1. Location of the study plots in Poland: Garwolin Forest, Białowieża Primeval Forest (BPF) and Pisz Forest.
New habitats in forests created after some anthropogenic disturbances are very similar to those created after natural disturbances: both are shortlived and remain suitable for pioneer species (Southwood 1962, Travis \& Dytham 1999, Brändle et al. 2000).

Previous studies on Phoridae inhabiting areas after disturbances show that the disturbed areas created by fire are remarkably diverse and species-rich with respect to this insect group (Durska et al. 2010). Many of these are a major component of the pioneer fauna that recolonize habitats devastated by episodes such as clearcutting, windstorms or forest fires (Durska 2006, 2009, Durska et al. 2010, Żmihorski \& Durska 2011, Durska 2013). Both fire intensity and environmental heterogeneity influence two components of post-fire faunal communities: animals that have survived the fire and colonizers from the surrounding habitats.

The present study complements previous research on the response of scuttle fly communities to disturbances in pine forests of the Polish Lowland (see Durska 2013). Specifically, the aim of this study was to compare scuttle fly communities colonizing fire-affected forest habitats with communities colonizing forest habitats after anthropogenic (clearcutting, logging-windthrow) and natural (left-windstorm) disturbances. Scuttle flies, due to their highly diversified life cycles and environmental requirements, as well as relatively high number of species, could be useful to assess the stage of the community succession in disturbed habitat (Disney 1983a, 1994, Disney \&
Durska 1998, 2008, Mikulski et al. 2009, Disney \& Durska 2011, Durska 2013, Ng'endo et al. 2013, Malewski et al. 2015).

\section{Materials and methods}

\subsection{Study sites}

The Garwolin Forest (GF) (51 ${ }^{\circ} 58^{\prime} 7^{\prime \prime}$ N, 21 ${ }^{\circ} 39^{\prime}$ $40 " \mathrm{E}$ ) is located in Central Poland (Fig. 1). The forest, mostly on sandy soil, comprises nutrientpoor to semi-rich habitats, with understorey vegetation dominated by mosses (Polytrichum spp.), grasses (Calamagrostis spp., Deschampsia flexuosa) and shrubs (Rubus spp., Vaccinium spp.). Moist pine forest found in the GF is represented by Peucedano-Pinetum in its subboreal variety (Matuszkiewicz et al. 1993). The tree stands are composed mainly of Scots pine (Pinus sylvestris), with a lower proportion of Norway spruce (Picea abies), oaks (Quercus spp.), birches (Betula spp.) and occasional other species (Matuszkiewicz et al. 1993). On 6 July 2010 an anthropogenic fire destroyed approximately 1.5 ha of the GF. A small open-area habitat, in which weak fire had destroyed the under storey, was left for natural regeneration. Three plots were selected: plot G I in the center of the fire zone; plot $\mathrm{G}$ II, adjoining plot $\mathrm{G} I$ and approximately $10 \mathrm{~m}$ from the border of plot G I; and plot G III, a control plot, $10 \mathrm{~m}$ from the border of plot G II. Plots G II and G III were placed further away from the burnt area (in a straight line). 


\subsection{Site with forest fire}

Scuttle flies in the GF were collected in the second and third year after the fire episode (2012 and 2013). The stand age was 50 years old.

The material was collected using yellow plastic pans, $18 \mathrm{~cm}$ in diameter, containing water, $75 \%$ ethylene glycol and some detergent (Bańkowska \& Garbarczyk 1982). Three traps were placed in each of the sampling plots at ground level in a straight line (altogether nine traps every $10 \mathrm{~m}$ ). The trapping lasted from May through October and traps were emptied fortnightly.

Identification was conducted under a dissecting microscope with the material transferred to glycerol. Analyses based on the Megaselia Rondani species used only male individuals, as most females of Megaselia spp. are not identifiable at species level. For determination, the keys of Disney (1983b, 1989), Schmitz (1938-1958) and Schmitz et al. (1974-1981) were used. The material from this study is deposited at the $\mathrm{Mu}-$ seum and Institute of Zoology (PAS), Warsaw, Poland and the University of Cambridge, $\mathrm{Mu}-$ seum of Zoology, UK.

\subsection{Sites used for comparison}

The data obtained from the plot in the center of the fire zone (G I) were compared to the data obtained for scuttle fly communities inhabiting pine forests (Białowieża Primeval Forest and Pisz Forest) after anthropogenic (clearcutting, loggingwindthrow) and natural (left-windthrow) disturbances, as well as with scuttle fly communities from an intact forest habitat (old-growth) (for details see Durska 2013).

Scuttle flies in Białowieża Primeval Forest (BPF) were collected in 1986 and 1987. In BPF, the plots were randomly selected within evenaged pine plantations as well as within oldgrowth stands. In Pisz Forest (PF), scuttle flies were collected in 2005, three years after a windstorm, from six stations in the natural windthrow (i.e. left-windthrow as habitat type) and from five stations in the managed windthrow (i.e. logged- windthrow as habitat type) (for details see Żmihorski \& Durska 2011, Durska 2013).

It is worth stressing that the vegetation type and period of time after disturbance (ca. 3 years) of these compared forest habitats (pine forest BPF and PF) are similar to the habitat and time after disturbance of the habitats in the Garwolin Forest (GF).

\subsection{Statistical analysis}

Species diversity of scuttle fly communities recorded in the three plots of GF (G I, G II, G III), in the compared habitats (clear-cut of BPF and leftand logged-windthrow plots of PF) as well as in the old-growth stands of BPF were assessed with the help of rarefaction curves implemented in EstimateS 800 software. Coleman rarefaction curves were used in order to estimate the expected cumulative number of species for a given number of sampled individuals. In addition, the total species richness, corrected for unseen species in the samples, was also assessed. For this purpose an Abundance-based coverage estimator (ACE) and Chaol estimator (Colwell 2005, Chao et al. 2006) were applied. This method uses the abundance of rare species ( $n \leq 10$ individuals) in samples to estimate the number of unseen species and is commonly used in faunistic research (Chao et al. 2006).

To assess the similarity of the scuttle fly communities in the forest habitats studied, three indices were calculated: Sørensen (operating only with the number of common and separated species), Baroni-Urbani (operating only with the number of common, separated and absent species), and Morisita-Horn (operating with the number of individuals of each species) (Wolda 1981).

Cluster analysis was performed by using these indices as similarity functions and an agglomeration method: group of $k$ samples with $n_{i, j}$ individuals of $i$ species in $j$ samples was treated as one sample with $n_{i, j_{1}}+n_{i, j_{2}}+\ldots+n_{i, j_{k}}$ individuals of $i$ species. Finally, the three similarity dendrograms were created. 


\section{Results}

\subsection{Characteristics of scuttle fly communities after fire}

Among 8,702 specimens of scuttle flies collected on the three plots in the GF (Table 1), particular attention was paid to the data concerning 1,243 specimens (all identifiable males of Megaselia spp., plus males and females of Phoridae from other genera) belonging to 48 species, including one unidentified species each of the Megaselia giraudii-complex and $M$. pulicaria-complex (Table 2). Situated at a short distance, the number of species $(S)$ and individuals $(n)$ were almost the same on the three plots (Table 2).

In the three plots of GF (G I, G II, G III) eleven species of the genus Megaselia, and Anevrina unispinosa (Zetterstedt), Borophaga subsultans (Linné), Conicera similis (Haliday) and Triphleba luteifemorata (Wood) were found in relatively high numbers $(n>10$ male specimens in at least one sampling plot). Among these Megaselia dominants of the open-area habitats, three species (polysaprophagous M. brevicostalis (Wood), saprophagous M. nigriceps (Loew 1866), and zoophagous $M$. elongata (Wood)) were found in the highest numbers in the plot most affected by fire (G I). However, Megaselia verralli (Wood), a known pyrophilous species (Prescher et al. 2002) dominant in pine forest habitats after disturbances in Poland (Durska 2013), was found in very low abundance in the GF habitats (G I: $n=3$; G II: $n=1$; G III: $n=1$ ) (Table 2).

Scuttle fly species with known biologies, accounted for $70.8 \%(S=34)$ of the compared species (Table 2). The majority of the species in the three habitats were the species with sapro/mycophages larvae $(S=27)$ and a multivoltine life cycle. These species are most active during spring and autumn (for details see Durska 2013). Among the species with zoophagous larvae, e.g. Aenigmatias lubbockii (host: ants), Megaselia aequalis (host: slug eggs), M. elongata (host: millipedes), $M$. flavicoxa (host: sciarid larvae), $M$. obscuripennis (host: sciarid larvae), Phalacrotophora berolinensis (host: coccinellid pupae), and Triphleba lugubris (host: wasp brood) Megaselia elongata was the most abundant on the plot in the
Table 1. Abundances and diversity of Phoridae in Garwolin Forest, years 2012 and 2013. Plot G I post-fire, plot G II - not affected by fire, plot G III control plot, not affected by fire.

\begin{tabular}{lrrr}
\hline & G I & G II & G III \\
\hline No. of individuals & 2,569 & 3,110 & 3,023 \\
No. of Megaselia males & 351 & 311 & 255 \\
No. of determined males & 295 & 251 & 220 \\
No. of Megaselia females & 2,117 & 2,625 & 2,563 \\
No. of determined species & 37 & 36 & 42 \\
Shannon - Weaver index & 4.2688 & 4.1689 & 4.2699
\end{tabular}

center of the fire zone $(\mathrm{G} \mathrm{I})$ compared to the two other plots (G I: $n=36$; G II: $n=22$; G III: $n=19$ ) (Table 2). Some species of polysaprophagous $M$. pulicaria-complex are specialized predators of spider eggs (Table 2) (Disney 1994).

\subsection{Diversity of scuttle fly communities}

The scuttle fly communities found in the two plots most affected by fire (G I and G II) were similar in terms of the number of species for a given number of sampled individuals and less diverse than the habitat not affected by fire (G III). Estimation of total species richness corrected for unseen species in samples (ACE and Chaol corrected) confirms this result (Table 2).

Compared to the scuttle fly communities occurring in the post-disturbance habitats (clearcut, left- and logged windthrow), the GF plot most affected by fire (center of fire, plot G I) appeared to be the most similar to the habitat of the clear-cut stand (BPF) with regard to the number of species for a given number of sampled individuals, followed by the left- and logged windthrow habitats (PF). Estimations of total species richness corrected for unseen species in samples (ACE and Chaol) for the old-growth stands (BPF) is about three times as high as for the postfire (G I) and clear-cut (BPF) stands (Fig. 2).

\subsection{Similarity of scuttle fly communities}

The similarity of the scuttle fly communities in the three compared plots in Garwolin Forest was 
Table 2. Species abundances per site in Garwolin Forest in 2012 and 2013 and larval diet. Plot G I - post-fire, plot G II - not affected by fire, plot G III - control plot, not affected by fire. Dominant species ${ }^{\#}$, at least at one site type with at least 10 individuals, are shown in bold type.

\begin{tabular}{|c|c|c|c|c|}
\hline Species & GI & G II & G III & Larval diet \\
\hline Aenigmatias lubbockii (Verrall1877) & 4 & 1 & 1 & Zoophagous \\
\hline Anevrina unispinosa (Zetterstedt 1860) & 14 & 36 & 72 & Necrophagous \\
\hline Borophaga subsultans (Linné 1767) & 18 & 56 & 33 & Unknown \\
\hline Conicera similis (Haliday 1833) & 39 & 50 & 56 & Necrophagous \\
\hline Conicera tibialis Schmitz 1925 & 4 & 1 & 1 & Necrophagous \\
\hline Gymnophora quartomollis Schmitz 1920 & & & 4 & Necrophagous $^{\$}$ \\
\hline Megaselia abdita Schmitz 1959 & 4 & 10 & 9 & Necrophagous \\
\hline Megaselia aequalis (Wood 1909) & & & 1 & Zoophagous \\
\hline Megaselia albicaudata (Wood 1910) & 2 & & & Unknown \\
\hline Megaselia altifrons (Wood 1909) & 2 & & 4 & Saprophagous $\$$ \\
\hline Megaselia berndseni (Schmitz 1919) & & 2 & & Mycophagous \\
\hline Megaselia brevicostalis (Wood 1910) & 70 & 25 & 11 & Polysaprophagous \\
\hline Megaselia brevior (Schmitz 1924) & & & 1 & Unknown \\
\hline Megaselia campestris (Wood 1908) & 10 & 15 & 12 & Unknown \\
\hline Megaselia diversa (Wood 1909) & 1 & 1 & 1 & Saprophagous $^{\$}$ \\
\hline Megaselia eisfelderae Schmitz 1948 & 5 & 7 & 3 & Mycophagous \\
\hline Megaselia elongata (Wood 1914) & 36 & 22 & 19 & Zoophagous \\
\hline Megaselia emarginata (Wood 1908) & 0 & 1 & 0 & Unknown \\
\hline Megaselia flavicoxa (Zetterstedt 1848) & 7 & 4 & 6 & Zoophagous \\
\hline Megaselia frameata Schmitz 1927 & & 2 & & Mycophagous \\
\hline Megaselia fumata (Malloch 1909) & 1 & 1 & 4 & Unknown \\
\hline Megaselia fusca (Wood 1909) & 4 & 3 & 2 & Saprophagous \\
\hline Megaselia giraudii-complex & 6 & 19 & 6 & Polyphagous \\
\hline Megaselia ignobilis (Schmitz 1919) & 1 & & & Unknown \\
\hline Megaselia lata (Wood 1910) & 7 & 3 & 4 & Mycophagous \\
\hline Megaselia latifrons (Wood 1910) & 15 & 19 & 12 & Unknown \\
\hline Megaselia longicostalis (Wood 1912) & 5 & 5 & 9 & Necrophagous \\
\hline Megaselia lutea (Meigen 1830) & 4 & 9 & 13 & Mycophagous \\
\hline Megaselia major (Wood 1912) & 1 & 1 & & Unknown \\
\hline Megaselia manicata (Wood 1910) & & & 1 & Unknown \\
\hline Megaselia meconicera (Speiser 1925) & 3 & 2 & 4 & Saprophagous $^{\$}$ \\
\hline Megaselia minor (Zetterstedt 1848) & 6 & 2 & 6 & Necrophagous \\
\hline Megaselia nigriceps (Loew 1866) & 13 & 6 & 1 & Saprophagous \\
\hline Megaselia obscuripennis (Wood 1909) & 13 & 10 & 10 & Zoophagous \\
\hline Megaselia pleuralis (Wood 1909) & 6 & 1 & 3 & Polysaprophagous \\
\hline Megaselia propinqua (Wood 1909) & 4 & 4 & 4 & Unknown \\
\hline Megaselia pulicaria - complex & 48 & 56 & 47 & Polysaprophagous \\
\hline Megaselia pumila (Meigen 1830) & 1 & & 3 & Mycophagous \\
\hline Megaselia ruficornis (Meigen 1830) & & & 2 & Necrophagous \\
\hline Megaselia scutellaris (Wood 1909) & 16 & 19 & 16 & Mycophagous \\
\hline Megaselia sylvatica (Wood 1910) & & & 1 & Mycophagous \\
\hline Megaselia testacea (Lundbeck. 1920) & & & 1 & Unknown \\
\hline Megaselia verralli (Wood 1910) & 3 & 1 & 1 & Unknown \\
\hline Megaselia zonata (Zetterstedt 1838) & 1 & 1 & 3 & Unknown \\
\hline Metopina oligoneura (Mik 1867) & 1 & 2 & 2 & Polysaprophagous \\
\hline Phalacrotophora berolinensis Schmitz 1920 & 1 & 1 & 1 & Zoophagous \\
\hline Triphleba lugubris (Meigen 1830) & & & 1 & Zoophagous \\
\hline Triphleba luteifemorata (Wood 1906) & 20 & 25 & 33 & Necrophagous \\
\hline Total no. of individuals per site & 396 & 423 & 424 & \\
\hline Total no. of species per site & 37 & 36 & 42 & \\
\hline Expected no. of species - $A C E^{\varepsilon}$ & 41.8 & 47.7 & 53.3 & \\
\hline Expected no. of species - Chao 1 & 53.0 & 46.0 & 43.5 & \\
\hline Expected no. of species - Chao1 corrected & 46.3 & 43.5 & 58.5 & \\
\hline
\end{tabular}

\# Durska 2013. - \$ Probable diet of larvae. - £ Abundance-based coverage estimator. 


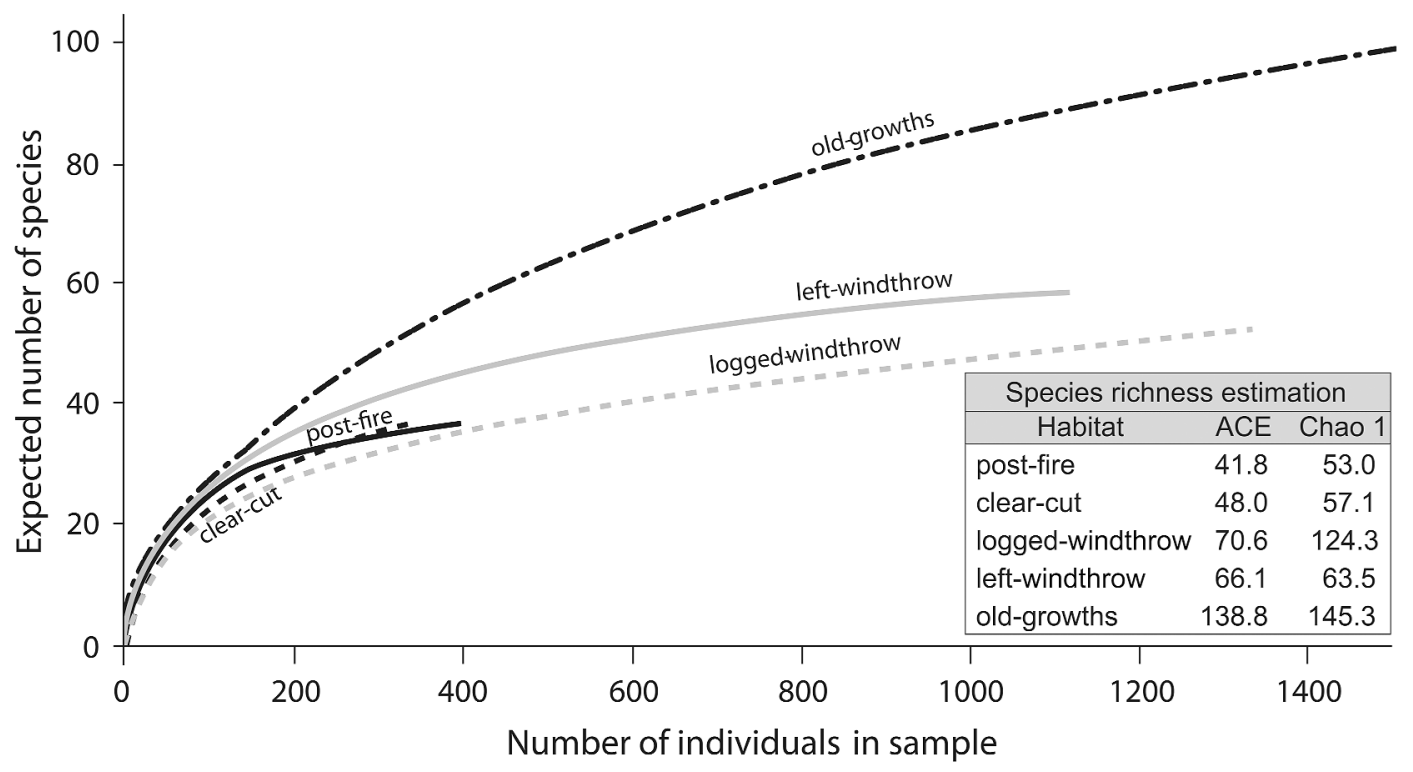

Fig. 2. The expected cumulative number of scuttle fly (Phoridae) species as a function of number of sampled individuals in five habitat types. Estimated species richness, corrected for species unseen in samples, is given in the box. ACE (abundance-based coverage estimator) and Chao 1 are non-parametric, asymptotic species richness estimators for abundance-based data.

very high. The Sørensen index between $G$ I and G II plots was the highest, and amounted to 0.92 (between G I and G III: $S \varnothing=0.87$; between G II and G III: $S ø=0.83$ ).

The scuttle fly community recorded in the GF in the plot most affected by fire (G I) shows greater similarity to those in the clear-cut stand in Białowieża Primeval Forest and in the left- and logged-windthrow plots in Pisz Forest than to the community of scuttle flies in old-growth stands in Białowieża Primeval Forest (indices of similarity: Sørensen, Baroni-Urbani and Morisita-Horn) (Fig. $3 \mathrm{a}, \mathrm{b}, \mathrm{c}$ ).

\subsection{Megaselia species and sex ratio}

In the studied material, the species from the genus Megaselia constituted almost $80 \%(S=38)$ of all recorded species, and the female individuals of this giant genus accounted for over $80 \%$ of the scuttle fly community associated with each plot in the GF (G I $=82.41 \%$; G II $=84.41 \%$; G III $=$ $84.78 \%$ ). The average male-to-female ratio of the genus Megaselia amounted to $0.13(n=8,222)$ (Table 1).

\section{Discussion}

In previous studies I found that several species of Phoridae preferred the disturbed areas while others were found to be more numerous in the intact forests (old-growth stands) (Durska 2003, Durska et al. 2010, Durska 2013). Moreover, the open-area species of scuttle fly communities respond in a parallel way to different disturbances (Durska 2013). A similar response to disturbances (clear-cutting, grazing and burning) was also found for spider and carabid faunas (Gibson et al. 1992, Coddington et al. 1996, Zulka et al. 1997, Moretti et al. 2002, Fernández \& Costas 2004, Huber \& Baumgarten 2005).

As was documented in previous studies (Durska 2013 and literature therein) for scuttle fly communities in pine forests of the Polish Lowland, specimens of Megaselia $(S=38)$ constituted the largest part of the material collected in Garwolin Forest (Table 1). The species affecting functional diversity analyses (Fontaine et al. 2006, Hillebrand \& Matthiessen 2009) are the Megaselia species, as females of this genus accounted for over $80 \%$ of all the communities found in the three sampled plots (G I, G II and G 

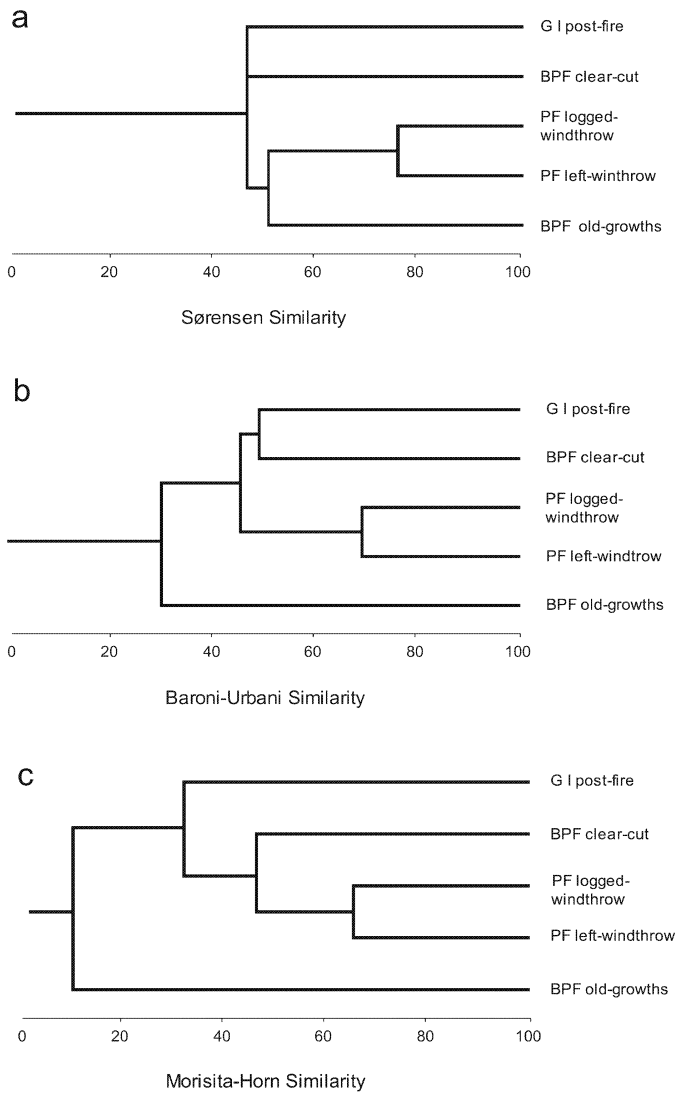

Fig. 3. Cluster analyses of pine forests, using the indices of similarity (presence/ absence of species),

showing that post-fire habitat (G I), young pine plantation (BPF clear-cuts) and post-windstorm habitats (PF logged-windthrow and PF left-windthrow) shared relatively similar scuttle fly communities, while intact forest stand (BPF old-growths) composes a second group.

- a. Sørensen Similarity. - b. Baroni-Urbani Similarity. - c. Morisita-Horn Similarity.

III) in the Garwolin Forest (Table 1). The maleto-female sex ratio using the yellow pan method reached 0.13 , in contrast to data obtained from habitats after wildfires in Castanea sativa forests in the Swiss Alps (emergence traps), and in a hemiboreal forest in Tyresta near Stockholm (Malaise traps), where males predominated (Prescher et al. 2002, Durska et al. 2010). It is worth adding that the sex ratios of Phoridae obtained in field collection, compared to those from rearings, are often dominated by one sex (Disney 1994). Furthermore, both dominants of open area habitats, $M$. brevicostalis and $M$. verralli were found in great numbers during studies in old- growth pine stands (yellow pans placed at the ground level) in Białowieża Primeval Forest (Durska 1996, Durska unpubl.). Based on the above data, it can be concluded that the differences in sex ratios obtained in these studies are related not only to the behaviour between the sexes, but also to the trapping method (Table 1, 2) (Disney 1994, Prescher et al. 2002, Durska et al. 2010, Durska 2013).

It is well known that disturbances can promote species richness in forests (Similä et al. 2002, Sippola et al. 2002). The present results showed that the majority of species in the three plots in Garwolin Forest were the species of small body size with sapro/mycophagous larvae and a multivoltine life cycle (Table 2). The same results were found by Durska et al. (2010) and Durska (2013). In addition, the species richness of the scuttle fly community after anthropogenic disturbances in the fire-affected plot in the GF (G I) and in the young pine plantation in BPF were remarkably similar to each other and lower than those found in habitats with natural disturbances (up to 1.7 times lower than post-windstorm habitats and three times lower than old-growth stands.) (Fig. 2). Furthermore, when comparing scuttle fly communities after anthropogenic fire (Garwolin Forest - G I: $n=1,243 ; S=48$ ) with scuttle fly communities after natural fire (wildfire in Tyresta Forest near Stockholm, $n=8,051 ; S=112$ ), the same Megaselia species were dominant (Tyresta Forest: $M$. nigriceps, $M$. pulicaria-complex and M. brevicostalis) (Durska et al. 2010). Megaselia pulicaria-complex and $M$. brevicostalis were also dominant in the post-wildfire scuttle fly communities in Castanea sativa forests in the Swiss Alps (Prescher et al. 2002).

Despite the fact that the three plots in Garwolin Forest were situated at a short distance, the response of the flies to the disturbance, in this case fire, was species-specific. Four dominant Megaselia species (the polysaprophagous $M$. brevicostalis, saprophagous $M$. nigriceps and, zoophagous M. elongata and $M$. obscuripennis) were found in the highest numbers in the plot the most affected by fire (G I) (Table 2). Many scuttle fly species are known to be very sensitive to changes in their habitat, especially to climatic conditions (Folgarait et al. 2007). During dry seasons, the characteristic dominant species of open-area hab- 
itats, $M$. brevicostalis reaches its abundance peak much earlier than in years when humidity is typical (Disney et al. 1981). Furthermore, also Megaselia verralli, another characteristic dominant scuttle fly species in communities in the pine plantations (clear-cut) of the Polish Lowland as well as in the post-wildfire habitats in the Castanea sativa forests (Swiss Alps), was found in the fire-affected plot (GI). However, the number of individuals was extremely low $(n=3)$ (Table 2$)$ (Prescher et al. 2002, Durska 2006, 2009, 2013).

Polysaprophagous and saproxylic $M$. pleuralis (Godfrey \& Disney 2002), an extraordinarily abundant species after the wildfire in Tyresta Forest (near Stockholm) and also dominant in the clear-cut habitat in BPF as well as in the loggedwindthrow habitat in $\mathrm{PF}$, reached the highest abundance in the fire-affected plot (G I) in Garwolin Forest (Durska et al. 2010, Bonet et al. 2011, Durska 2013). Three Megaselia species (i.e. $M$. nigriceps, $M$. elongata, $M$. obscuripennis) were also the dominant species in the scuttle fly community collected in Karkonosze National Park (Poland) using bark traps placed on spruce and on pine logs in unaffected forests, both with Fomitopsis pinicola (Sw.) P. Karst (Polyporales) (Durska unpubl.).

Flying zoophagous arthropods are known as one of the most fire-resistant groups with the highest resilience to fire (Wikars 2001, Hanula \& Wade 2003, Parr et al. 2004, Arnan et al. 2006). Megaselia elongata with zoophagous larvae were most abundant on the most fire-affected plot (G I) compared to the two other plots (G II and G III) (Table 2). Furthermore, the ant parasitoid Aenigmatias lubbockii, reached the highest numbers in the most fire-affected plot (G I). Prescher et al. (2002) also found a high number of individuals $(n=18)$ of the genus Aenigmatias (i.e. $A$. dorni Enderlein) after wildfires in the Castanea sativa forests (Swiss Alps). The hosts of $A$. lubbockki (Formica ants) avoid shaded nest locations because they have high thermal requirements.

Species composition after fire varies depending on fire intensity. In addition, some insect species are associated with canopy fire, some with the amount of vegetation and shrub cover, and some with how much time has passed since the fire occurred. Furthermore, some species are not dependent on fire or vegetation cover (Rodrigo et al. 2008). When comparing the species composition of scuttle fly communities after different disturbances, the community in the fire-affected plot (G I) in Garwolin Forest shows the greatest similarity to those from the habitats after anthropogenic disturbances, i.e. the clear-cut stand in BPF and the logged-windthrow plots in PF. Similarity to the communities in the left-windthrow plots in Pisz Forest was less. The least similar community to that in the fire-affected Garwolin Forest plot ( $G$ I) was found in the undisturbed old-growth stands in Białowieża Primeval Forest (Fig. 3) (Durska 2013).

Forest fires have many implications for biological diversity and not all species suffer from fire. It is known that the speed of recovery after fire is related to the fire intensity, and some invertebrates and fungi are dependent on or favored by fire (Dahlberg 2002, Saint-Germain et al. 2004, Penttilä et al. 2013). The larvae of saprophagous and mycophagous Megaselia species, including $M$. frameata found in Garwolin Forest (G II) and in Tyresta Forest near Stockholm, are feeding or breeding in polypore fungi (Disney 1994). Moretti et al. (2006) found that the functional groups, i.e. the ground-litter saprophages and the saproxylophages, recovered in 6-14 years after a single fire. Futhermore, Penttilä et al. (2013) demonstrated that after fire, polypore species of dead wood recovered to the pre-fire level six years after the fire and were more abundant in the semi-natural stand, with a larger amount and variety of dead wood than in the managed stand. The way dead wood is formed (natural or anthropogenic processes) influences the polypore fungi. The results of the study were consistent with other studies which showed that wood-inhabiting fungi seem to be adapted to disturbances and are connected with open-area habitats (Penttilä et al. 2013). The successional pathways of sapro/ mycophagous Phoridae, especially from the genus Megaselia, seem to be inseparably related (ecological niche) to the stages of succession of the polypore fungi on dead wood created after disturbances (Speight 1989, Disney 1994, Disney \& Pagola-Carte 2009, Ulyshen \& Hanula 2010, Komonen et al. 2014).

The sun-exposed microhabitats arising after natural and anthropogenic disturbances are suit- 
Table 3. Expression profile of heat shock proteins genes (Hsp) of larvae $\left(1 \mathrm{~h}\right.$ at $\left.39^{\circ} \mathrm{C}\right)$ and the functions of small heat shock proteins (sHsp).

\begin{tabular}{cccl}
\hline Genes & Drosophila melanogaster & Megaselia scalaris & Functions of heat shock proteins ${ }^{\#}$ \\
\hline Hsp22 & 53.1 & Induction & Cell protection against oxidative stress \\
Hsp23 & 6.1 & 3.5 & Control of ecdysis and metamorphosis \\
Hsp26 & 2.9 & 0.2 & Protective role in nervous system \\
Hsp27 & 0.1 & 1.2 & Stress resistance, partly block apoptosis \\
Hsp40 & 0.1 & 2.3 & Co-factor of Hsp70, i. a. thermoadaptation \\
\hline
\end{tabular}

\#) Mestril et al. 1986, Morrow et al. 2004, Awofala et al. 2011 and references therein, Zhao et al. 2011 and references therein.

able for those scuttle fly species which are sapro/ mycophagous or predators/parasitoids of other mycophagous invertebrates. Megaselia flavicoxa and $M$. obscuripennis, parasitoids of sciarid larvae (fungus gnats) (Disney 1994), were found in the highest numbers in the plot most affected by fire in Garwolin Forest (G I). Megaselia flavicoxa was previously found in the post-windthrow habitat in Pisz Forest $(n=39)$ and in the old-growth habitat in the Białowieża Primeval Forest $(n=1)$ (Durska 2013). On the other hand, M. obscuripennis was also found in the traps deployed directly after wildfire (Tyresta Forest near Stockholm) on spots exposed to strong heat-related soil destruction (Durska et al. 2010). As was found previously, the mycophagous species of the scuttle fly communities reached a higher abundance in young pine plantations (clear-cut plots) and logged-windthrow habitats than in the oldgrowth and left-windthrow plots (Durska 2013: fig. 4.). High similarity of the scuttle fly communities found in the plot after fire (G I) in Garwolin Forest, in young clear-cut plots (BPF), and in logged-windthrow areas (PF) is not surprising as these three habitat types have common features: similar insolation and humidity (see: Durska 2013) as well as fungi at the same phase of succession (i.e. about 3 years after disturbance) (Kaila et al. 1994, Stokland \& Larsson 2011, Ottosson et al. 2014).

The present study is the continuation of research on the scuttle fly communities inhabiting disturbed areas in pine forests of the Polish Lowland. The studies on Phoridae of fire-affected areas in Garwolin Forest were conducted using the same method of trapping (yellow pans) and in a similar habitat (pine forest). Both studies were also conducted about 3 years after disturbance, i.e. with a similar stage of secondary succession with similar above ground-below ground interactions. Thus, it is assumed that the species-specific similarity in response to disturbances remains plausible (De Deyn \& Van der Putten 2005, Durska 2013).

The Megaselia species are the winners in disturbed, sun-exposed habitats and seem to be more stress-tolerant than other genera of scuttle flies. Moreover, a greater resistance to stress and disturbance in Megaselia females (very high abundance in disturbed habitats, see: Durska 2013) could be linked to differences in body lipid accumulation and, even more likely, a better evolutionary adaptation to high temperature (Table 1) (Bauerfeind et al. 2014, Malewski et al. 2015).

There are few molecular-based researches on ecological problems connected with temperature, insect species abundance and geographical distribution (Leather et al. 1993, Johanson et al. 2009). The scuttle flies, dominating in open-area habitats, are lured by heat, smoke, carbon dioxide and other volatile compounds to open-areas abundant in dead wood, which is decomposed by fungi to organic matter rich in the limiting factor, phosphorus (Klocke et al. 2011, Luke et al. 2014). Furthermore, phosphorus, as essential for life, is also required for the synthesis of heat shock proteins, which protect each living cell against heat stress and other stresses in a disturbed habitat (Jiang et al. 2009).

During my concurrent studies on the polyphagous M. scalaris (Loew) and Drosophila melanogaster Meigen (control group), after exposing the larvae to high temperatures exceeding $39^{\circ} \mathrm{C}$, expression of $H s p$ genes was compared. Among others, it was found that the expression profile of $H s p$ genes is species-dependent and 
down-regulated for the three heat shock protein genes Hsp22, Hsp23 and Hsp26 of M. scalaris when compared to D. melanogaster (Table 3) (Malewski et al. 2015). The same results were obtained in the studies on necrophagous $M$. abdita (found in G I, G II, G III - Table 2), the species native to Central Europe (Malewski \& Durska unpubl.).

Available literature stresses how heat shock proteins ensure survival under conditions of environmental stress, which in the absence of a defensive reaction can lead to irreversible changes in, and permanent damage to, cells (Mestril et al. 1986, Morrow et al. 2004, Awofala et al. 2011, Zhao et al. 2011).

Perhaps the dominant, scuttle fly species, which prefer disturbed, open-area habitats rich in phosphorus (Mulder et al. 2013), can be strongly influenced by a genotype-by-temperature interaction, related to the expression of heat shock protein genes (Luke et al. 2014, Malewski et al. 2015). Significant ecological issues could be resolved if molecular studies would be applied (Johnson et al. 2009).

\section{Conclusions}

Overall, the study revealed and confirmed a high similarity of scuttle fly communities inhabiting sun-exposed forest areas destroyed by anthropogenic fire to the communities after other kinds of disturbances (Durska 2013). The winners in the habitat following fire proved to be sapro/mycophagous Megaselia species (Disney 1994). Due to this conclusion, similar preferences of the scuttle fly species for disturbed habitats could be explained by a similar matrix structure of the inhabited areas (ca. 3 years after disturbance), characterized by a similar community of fungi, as a source of organic matter (Speith 1989, Worrall et al. 1997). Fungi provide a large amount of phosphorus, which is an extremely limited resource (Visanuvimol \& Bertram 2011) for the smallbodied scuttle flies in ephemeral habitats (Reaves et al 1990, Elsner et al. 2000; De Deyn \& Van der Putten 2005, Jiang et al. 2009; Prevedello \& Vieira 2010, Luke et al. 2014).

The present study indicates that the resilience (i.e. recovery over time) and resistance (i.e. heat stress tolerance) of the scuttle flies to anthropogenic and natural disturbances and their quick recolonization of sun-exposed areas (Durska 2013) could be an evolutionary adaptation to high temperatures (Malewski et al. 2015).

Acknowledgements. I wish to thank Matthias Buck for his critical review of the previous version of the manuscript. I would like to thank an anonymous reviewer for the valuable suggestions and helpful comments. I thank Marcin Zalewski and Jolanta Wytwer for their kind advice on a previous version of this manuscript. I am grateful to Dr R. Henry L. Disney for his invaluable support during my work on Phoridae. I wish to thank Miłosława BarkowskaSokół for help in statistical analyses, and Jodie Baltazar, who kindly improved the English. I also thank Krzysztof Gagla for his valuable assistance with the sorting of the material. Finally, I would like to thank Andrzej Bartha and Jadwiga Kocyba for their help with the graphic art of figures. The author benefitted from SYNTHESYS support made available by the European Community - Research Infrastructure Action under the FP6 Structuring the European Area Programme AT-TAF 543 and SE-TAF 1833. My research on Phoridae is supported by a grant from $\mathrm{Na}-$ tional Science Centre (NCN) (nr 2011/01/B/NZ8/03005).

\section{References}

Arnan, X., Rodrigo, A. \& Retana, J. 2006: Post-fire recovery of Mediterranean ground ant communities follows vegetation and dryness gradients. - Journal of Biogeography 33(7): 1246-1258.

Awofala, A. A., Jones, S., \& Davis, J. A. 2011: The heat shock protein 26 gene is required for ethanol tolerance in Drosophila. - Journal of Experimental Neuroscience 5: $31-44$.

Bańkowska, R. \& Garbarczyk, H. 1982: Charakterystyka terenów badań oraz metod zbierania i opracowywania materiałów. In: Zoocenologiczne podstawy kształtowania środowiska przyrodniczego osiedla mieszkaniowego Białołęka Dworska w Warszawie. Part I. Skład gatunkowy i struktura fauny terenu projektowanego osiedla mieszkaniowego. - Fragmenta Faunistica 26: 17-26.

Bauerfeind, S. S., Kellermann, V., Moghadam, N. N., Loeschcke, V.\& Fischer, K. 2014: Temperature and photoperiod affect stress resistance traits in Drosophila melanogaster. - Physiological Entomology 39: 237 246.

Bonet, J., Ulefors, S-O., Viklund, B. \& Pape, T. 2011: Species richness estimations of the megadiverse scuttle fly genus Megaselia (Diptera: Phoridae) in a wildfireaffected hemiboreal forest. - Insect Science 18(3): 325-348.

Brändle, M., Durka, W. \& Altmoos, M. 2000: Diversity of surface dwelling beetle assemblages in open-cast lignite mines in Central Germany. - Biodiversity and Conservation 9: 1297-1311. 
Chao, A., Li, P. C., Agatha, S. \& Foissner, W. 2006: A statistical approach to estimate soil ciliate diversity and distribution based on data from five continents. - Oikos 114(3): 479- 493.

Cobb, T. P., Morissette, J. L., Jacobs, J. M., Koivula, M. J., Spence, J. R. \& Langor, D. W. 2011: Effects of postfire salvage logging on deadwood-associated beetles. - Conservation Biology 25(1): 94-104.

Coddington, J. A., Young, L. H. \& Coyle, F-A. 1996: Estimating spider species richness in a southern Appalachian cove hardwood forest. - Journal of Arachnology 24: $111-128$.

Colwell, R. K. 2005: Estimates: statistical estimation of species richness and shared species from samples. Version 7.5. [www document]. URL http://www.purl. oclc.org/estimates. (Site visited 20 December 2010)

Dahlberg, A. 2002: Effects of fire on ectomycorrhizal fungi in Fennoscandian boreal forests. - Silva Fennica 36: 69-80.

De Deyn, G. B. \& Van der Putten, W. H. 2005: Linking aboveground and belowground diversity. - Trends in Ecology and Evolution 20: 625-633.

Disney, R. H. L. 1983a: A useful new character in the giant genus Megaselia (Diptera: Phoridae) with two new spwcies to Britain. - Zeitschrift fur Angewandte Zoologie 70: 225-234.

Disney, R. H. L. 1983b: Scuttle Flies. Diptera: Phoridae (except Megaselia). - Handbooks for the Identification of British Insects 10:1-81.

Disney, R. H. L. 1989: Scuttle Flies. Diptera: Phoridae, Genus Megaselia. - Handbooks for the Identification of British Insects 10: 1-155.

Disney, R. H. L. 1994: Scuttle flies: The Phoridae. Chapman and Hall, London. 467 pp.

Disney, R. H. L., Coluson, J. C. \& Butterfield, J. 1981: A survey of the scuttle flies (Diptera: Phoridae) of upland habitats in Northern England. - Naturalist, Hull 106: 53-66.

Disney, R. H. L. \& Durska, E. 1998: A new genus and species of Phoridae (Diptera) from Poland. - European Journal of Entomology 95: 437-453.

Disney, R. H. L. \& Durska, E. 2008: Conservation evaluation and the choice of faunal taxa to sample. - Biodiversity and Conservation 17:449 45.

Disney, R. H. L. \& Pagola-Carte, S. 2009: Two new species of Megaselia Rondani (Diptera: Phoridae) attracted to bracket fungi (Polyporaceae) in Spain. - Heteropterus Revista de Entomologia 9(2): 87-95.

Disney, R. H. L. \& Durska, E. 2011: Five new species and three new records of Megaselia Rondani (Diptera: Phoridae) from Pisz Forest (Poland). - Annales Zoologici 61(3): 527-534.

Durska, E. 1996: The species composition and structure of scuttle fly (Diptera: Phoridae) communities in mature tree stands in pine forests at different stages of habitat degradation. - Fragmenta Faunistica 39: 267-285.

Durska, E. 2003: The phenology of Triphleba Rondani species (Diptera: Phoridae) in moist pine forests in the Białowieża Forest. — Entomologica Fennica 14: 177 182.
Durska, E. 2006: Diversity of the scuttle fly (Diptera: Phoridae) communities in the plantations of moist pine forests of the Białowieża Primeval Forest and the Tuchola Forest (Poland). - Biodiversity and Conservation 15: 385-393.

Durska, E. 2009: The scuttle fly (Diptera, Phoridae) assemblages of pine plantations of the Biała Forest (Poland). - Entomologica Fennica 20:170-178.

Durska, E. 2013: Effects of disturbances on scuttle flies (Diptera: Phoridae) in Pine Forests. - Biodiversity and Conservation 22: 1991-2021.

Durska, E., Bonet, J. \& Viklund, B. 2010: The scuttle fly (Diptera: Phoridae) assemblages of a wildfire-affected hemiboreal old-growth forest in Tyresta (Sweden). Entomologica Fennica 21: 19-32.

Elsner, J. J., Sterner, R. W., Gorokhova, E., Fagan, W. F., Markow, T. A., Cotner, J. B., Harrison, J. F., Hobbie, S. E., Odell, G. M. \& Weider, L. J. 2000: Biological stoichiometry from genes to ecosystems. - Ecology Letters 3:540-550.

Fernández, M. M. \& Salgado Costas, J. M. 2004: Recolonization of burnt pine forest (Pinus pinaster) by Carabidae (Coleoptera). - European Journal of Soil Biology 40: 47-53.

Folgarait, P. J., Patrock, R. J. W. \& Gilbert, L. E. 2007: The influence of ambient conditions and space on the phenological patterns of a Solenopsis phorid guild in an arid environment. - Biological Control 42:262-273.

Fontaine, C., Dajoz, I., Meriguet, J. \& Loreau, M. 2006: Functional Diversity of Plant-Pollinator Interaction Webs Enhances the Persistence of Plant Communities. _ PLoS Biology 4: 0129-0135.

Fox, J. F. 1979: Intermediate disturbance hypothesis. Science 204: 1344-1345.

Gibson, C. W. D., Hambler, C. \& Brow, V. K. 1992: Changes in spider (Araneae) assemblages in relation to succession and grazing management. - Journal of Applied Ecology 29: 132-142.

Godfrey, A. \& Disney, R. H. L. 2002: Scuttle flies Diptera, Phoridae) from a large rothole in an oak tree in England. - Dipterists' Digest 9: 165-171.

Hanula, J. L. \& Wade, D. D. 2003: Influence of long-term dormant season burning and fire exclusion on grounddwelling arthropod populations in longleaf pine flatwoods ecosystems. - Forest Ecology and Management 175:163-184.

Hillebrand, H. \& Matthiessen, B. 2009: Biodiversity in a complex world: consolidation and progress in functional biodiversity research. - Ecology Letters 12: 1405-1419.

Holliday, N. J. 1984: Carabid beetles (Coleoptera. Carabidae) from burned spruce forest (Picea spp.). - Canadian Entomology 116: 919-922.

Holliday, N. J. 1991: Species responses of carabid beetles (Coleoptera: Carabidae) during post-fire regeneration of boreal forest. — Canadian Entomology 123: 1369 1389.

Huber, Ch. \& Baumgarten, M. 2005: Early effects of forest regeneration with selective and small scale clear-cutting on ground beetles (Coleoptera, Carabidae) in a 
Norway spruce stand in Southern Bavaria (Höglwald).

- Biodiversity and Conservation 14: 1989-2007.

Jiang, B., Wang, K., Liang, P., Xiao, W., Wang, H. \& Xiao, X. 2009: ATP-binding domain of heat shock protein 70 is essential for its effects on the inhibition of the release of the second mitochondria-derived activator of caspase and apoptosis in $\mathrm{C} 2 \mathrm{C} 12$ cells. - FEBS Journal 276(9): 2615-2624.

Johnson, J. B., Peat, S. M. \& Adams, B. J. 2009: Where's the ecology in molecular ecology? - Oikos 118: 1601-1609.

Kaila, L., Martikainen, P., Punttila, P. \& Yakovlev, E. 1994: Saproxylic beetles (Coleoptera) on dead birch trunks decayed by different polypore species. - Annales Zoologici Fennici 31: 97-107.

Keville, M. P, Reed, S. C. \& Cleveland, C. C. 2013: Nitrogen Cycling Responses to Mountain Pine Beetle Disturbance in a High Elevation Whitebark Pine Ecosystem. - PloS One 8: 1-8.

Klocke, D., Schmitz, A., Schmitz, H. 2011: Fire-Adaptation in Hypocerides nearcticus Borgmeier and Anabarhynchus hyalipennis hyalipennis Marquart and New Notes about the Australian "Smoke Fly" Microsania australis Collart (Diptera: Phoridae, Therevidae and Platypezidae). - The Open Entomology Journal 5: $10-14$

Knisley, C. B. 2011: Anthropogenic disturbances and rare tiger beetle habitats: benefits, risks, and implications for conservation. - Terrestrial Arthropod Reviews 4: 41-61.

Komonen, A., Halme, P., Jäntti, M., Koskela, T., Kotiaho, J. S. \& Toivanen, T. 2014: Created substrates do not fully mimic natural substrates in restoration: the occurrence of polypores on spruce logs. - Silva Fennica 48(1): $1-12$.

Leather, S., Walters, K. \& Bale, J. 1993: The ecology of insect overwintering. - Cambridge University Press, Cambridge. 257 pp.

Lee, S-I., Spence, J. R. \& Langor, D. W. 2014: Succession of saproxylic beetles associated with decomposition of boreal white spruce logs. - Agricultural and Forest Entomology 16: 391-405.

Luke, S. H., Fayle, T. M., Eggleton, P., Turner, E. C. \& Davis, R. G. 2014: Functional structure of ant and termite assemblages in old growth forest, logged forest and oil palm plantation in Malaysian Borneo. - Biodiversity and Conservation 23: 2817-2832.

Lyon, L. J., Crawford, H. S., Czuhai, E., Fredriksen, R. L., Harlow, R. F., Metz, L. J. \& Pearson, H. A. 1978: Effects of fire on fauna: A state-of-knowledge review. U.S. Department of Agriculture, Forest Service. 22 pp.

Malewski, T., Bogdanowicz, W., Durska, E., Loś, M., Kamiński, M. \& Kowalewska, K. 2015: Expression profiling of heat shock genes in a scuttle fly Megaselia scalaris (Diptera, Phoridae). - Journal of Experimental Zoology 9999A (In press.)

Matuszkiewicz, J., Degórski, M. \& Kozłowska, A. 1993: Description of the plant association structure and soils of pine forest stands situated in five regions of Poland. - Fragmenta Faunistica 36: 13-36.
Mestril, R., Schiller, P., Amin, J., Klapper, H., Anantha, J. \& Voellmy, R. 1986: Heat shock and ecdysterone activation of the Drosophila melanogaster hsp23 gene; a sequence element implied in developmental regulation. - EMBO Journal 5(7):1667-1673.

Mikulski, A., Grzesiuk, M., Kloc, M. \& Pijanowska, J. 2009: Heat shock proteins in Daphnia detected using commercial antibodies: description and responsiveness to thermal stress. - Chemoecology 19:69-72.

Moretti, M., Conedera, M., Duelli, P. \& Edwards, P. J. 2002: The effects of wildfire on ground-active spiders in deciduous forests on the Swiss southern slope of the Alps. - Journal of Applied Ecology 39: 321-336.

Moretti, M., Duelli, P., Obrist, M. K. 2006: Biodiversity and resilience of arthropod communities after fire disturbance in temperate forests. - Oecologia 149: 312 327.

Morrow, G., Samson, M., Michaud, S. \& Tanguay, R. M. 2004: Overexpression of the small mitochondrial Hsp22 extends Drosophila life span and increases resistance to oxidative stress. - FASEB Journal Doi: 10.1096/fj.03-0860fje

Mulder, C., Ahrestani, F. S., Bahn, M., Bohan, D. A., Bonkowski, M., Griffiths, B. S., Guicharaud, R. A., Kattge, J., Krogh, P. H., Lavorel, S., Lewis, O. T., Mancinelli, G., Naeem, S., Peñuelas, J., Poorter, H., Reich, P. B., Rossi, L., Rusch, G. M., Sardans, J. \& Wright, I. J. 2013: Connecting the green and brown worlds: Allometric and stoichiometric predictability of aboveand below-ground networks. - Advances in Ecological Research 49: 69-175.

Ng'endo, R. N., Osiemo, Z. B. \& Brandl, R. 2013: DNA barcodes for species identification in the hyperdiverse ant genus Pheidole (Formicidae: Myrmicinae). Journal of Insects Science 13: 1-13.

Ottosson, E., Norden, J., Dalhberg, A., Edman, M., Jönsson, M., Larsson, K-H., Olsson, J., Penttilä, R., Stenlid, J. \& Ovaskainen, O. 2014: Species associations during the succession of wood-inhabiting fungal communities. - Fungal Ecology 11:17-28.

Penttilä, R., Junninen, K., Punttila, P. \& Siitonen, J. 2013: Effects of forest restoration by fire on polypores depend strongly on time since disturbance - A case study from Finland based on a 23-year monitoring period. Forest Ecology and Managment 310: 508-516.

Platt, W. J. \& Connell, J. H. 2003: Natural disturbances and directional replacement of species. - Ecological Monographs 73: 507-522.

Prescher, S., Moretti, M. \& Duelli, P. 2002: Scuttle flies (Diptera, Phoridae) in Castanea sativa forests in the southern Alps (Ticino, Switzerland), with thirteen species new to Switzerland. - Mitteilungen der Schweizerischen entomologischen Gesellschaft 75: 289-298.

Prevedello, J. A. \& Vieira, M. V. 2010: Does the type of matrix matter? A quantitative review of the evidence. - Biodiversity and Conservation 19: 1205-1223.

Reaves, J. L., Shaw, C. G. \& Mayfield, J. E. 1990: The effects of Trichoderma spp. isolated from burned and non-burned forest soils on the growth and develop- 
ment of Armillaria ostoyae in culture. - Northwest Science 64: 39-44.

Rodrigo, A., Sardŕ-Palomera, F., Bosch, J. \& Retana, J. 2008; Changes of dominant ground beetles in black pine forests with fire severity and successional age. Ecoscience 15(4): 442-452.

Saint-Germain, M., Drapeau, P. \& Hébert, C. 2004: Comparison of Coleoptera assemblages from a recently burned and unburned black spruce forest of northeastern North America. - Biological Conservation 118:583-592.

Schmitz, H. 1938-1958: Phoridae. — In: Lindner, E. (ed.), Die Fliegen der palaearktischen Region IV(7). Schweizerbart, Stuttgart. 513 pp.

Schmitz, H., Beyer, E. \& Delage, A. 1974-1981: Phoridae (Fortsetzung). - In: Lindner, E. (ed.), Die Fliegen der palaearktischen Region IV(7). Schweizerbart, Stuttgart. $158 \mathrm{pp}$.

Similä, M., Kouki, J., Martikainen, P. \& Uotila, A. 2002: Conservation of beetles in boreal pine forests: the effects of forest age and naturalness on species assemblages. - Biological Conservation 106: 19-27.

Sippola, A. L., Siitonen, J. \& Punttila, P. 2002: Beetle diversity in timberline forests: a comparison between old-growth and regeneration areas in Finnish Lapland. - Annales Zoologici Fennici 39: 69-86.

Sousa, W. P. 1984: The role in disturbance in natural communities. - Annual Review of Ecology and Systematics 15: 353-391.

Southwood, T. R. E. 1962: Migration of terrestrial arthropods in relation to habitat. - Biological Reviews 37:171-214.

Speigth, M. C. D. 1989: Saproxylic invertebrates and their conservation. - Nature and Environmental Series, No 42. Council of Europe, Strasbourg. 79 pp.

Stokland, J. N. \& Larsson, K-H. 2011: Legacies from natural forest dynamics: Different effects of forest management on wood-inhabiting fungi in pine and spruce forests. - Forest Ecology and Management 261: 1707-1721.

Toivanen, T. \& Kotiaho, J. S. 2007: Mimicking natural disturbances of boreal forests: the effects of controlled burning and creating dead wood on beetle diversity. Biodiversity and Conservation 16: 3193-3211.

Travis, J. M. J. \& Dytham, C. 1999: Habitat persistence, habitat availability and the evolution of dispersal. Proceedings of the Royal Society of London, Series B: Biological Sciences 266: 723-728.

Ulyshen, M. D. \& Hanula, J. L. 2010: Patterns of saproxylic beetle succession in loblolly pine. - Agricultural and Forest Entomology 12(2): 187-194.

Vincent, K., Moening, K. \& Colter, H. 2009: Effects of annual fire on the litter fauna populations and soil compositions of an upland white-oak forest. - Tillers 6: $17-20$.

Visanuvimol, L. \& Bertram, S. M. 2011: How dietary phosphorus availability during development influences condition and life history traits of the cricket, Acheta domesticus. - Journal of Insect Science 11: 117.

Wikars, L-O. 2001: Immediate effects of fire-severity on soil invertebrates in cut and uncut pine forests. - Forest Ecology and Management 141:189-200.

Wolda, H. 1981: Similarity, sample size and diversity. Oecologia 50: 296-302.

Worrall, J. J., Anagnost, S. E. \& Zabel, R. A. 1997: Comparison of wood decay among diverse lignicolous fungi. - Mycologia 89: 199- 2019.

Zhao, H., Yang, H., Zhao, H., Chen, M. \& Wang,, T. 2011: The molecular characterization and expression of heat shock protein 90 (Hsp90) and 26 (Hsp26) cDNAs in sea cucumber (Apostichopus japonicus). — Cell Stress Chaperones 16(5): 481-493.

Zulka, K. P., Milasowszky, N. \& Lethmayer, Ch. 1997: Spider biodiversity potential of an ungrazed and grazed inland salt meadow in the National Park "Neusiedler See-Seewinkel" (Austria): implications for management (Arachnida: Araneae). - Biodiversity and Conservation 6: 75-88.

Żmihorski, M. \& Durska, E. 2011: The effect of contrasting management types on two distinct taxonomic groups in a large scaled windthrow. - European Journal of Forest Research 130: 589-600. 